\title{
An introduction to the 'new' politics of agriculture and food ${ }^{\text {t3 }}$
}

\author{
Carsten Daugbjerg ${ }^{\mathrm{a}, *}$, Alan Swinbank ${ }^{\mathrm{b}}$ \\ ${ }^{a}$ Institute of Food and Resource Economics, University of Copenhagen, Denmark \\ ${ }^{\mathrm{b}}$ School of Agriculture, Policy and Development, University of Reading, UK
}

\begin{abstract}
The agricultural policy agenda has been broadened with farm policy issues now interlinking with other policy domains (food safety, energy supplies, environmental protection, development aid, etc.). New actors promoting values which sometimes conflict, or which are not always easily reconcilable, with those previously guiding agricultural policy have entered the broader agricultural and food policy domain. The studies of various new policy issues inter-linking with the agricultural policy domain included in this special issue show that value conflicts are addressed in different ways and thus result in inter-institutional coordination and conflict unfolding differently. Studies of inter-institutional policy making in the agricultural policy sector have the potential to contribute to theoretical developments in public policy analysis in much the same way as agricultural policy studies did in the past.

(C) 2012 Policy and Society Associates (APSS). Elsevier Ltd. All rights reserved.
\end{abstract}

Keywords: Compartmentalised policy making; Decompartmentalism; Value conflict; Inter-institutional linkages; Policy layering

\section{Introduction}

Throughout much of the 20th Century, most industrialised countries intervened extensively in agricultural markets, frequently seeking to protect their farmers from international competition. In the aftermath of the Second World War, many of these policies were reinvented and reapplied, emphasising that agrarian fundamentalism, and the quest for food security, still prevailed. President Eisenhower (1956) for example, in a Special Address to the US Congress in January 1956, declared that 'In America, agriculture is more than an industry; it is a way of life. Throughout our history, the family farm has given strength and vitality to our entire social order. We must keep it healthy and vigorous' (see also Hathaway's comments on this, 1963, p. 7). Farmers were often depicted as the 'custodians of the countryside' (Cox \& Lowe, 1983, pp. 269-270) and providers of public goods, and free-markets were thought to be incapable of delivering these myriad goals. Political scientists called this agricultural exceptionalism (Coleman, Skogstad, \& Atkinson, 1997; Skogstad, 1998). This extended to exceptional institutional arrangements in the agricultural sector, in that agricultural policy making was undertaken in relatively closed policy networks of farm ministries and farm groups founded upon shared values (e.g. Coleman et al., 1997; Grant, 1995; Halpin, 2005). To a significant extent these closed networks controlled the policy process, and excluded other interests from influence. These developments at national level were reinforced internationally when, in the founding years of the GATT, the USA insisted on excluding

\footnotetext{
We are grateful to the other contributors for their helpful comments on earlier drafts of this text, and to the journal's referees, but retain sole responsibility for its contents.

* Corresponding author.

E-mail addresses: cda@foi.ku.dk (C. Daugbjerg), A.Swinbank@reading.ac.uk (A. Swinbank).
} 
agriculture from a number of the newly agreed disciplines on international trade (Josling, Tangermann, \& Warley, 1996; Wilcox, 1949).

In the past two decades the traditional agricultural policy agenda in developed countries has been challenged by new policy issues. No longer is 'farm income' the prime focus; although food security has been reinvigorated as a policy concern following the food price scares of the late 2000s, and the re-realization that a world populated by, possibly, 9 billion people in 2050, together with the adoption of a more westernised diet, could lead to a 50\% increase in world food demand (Huang, Legg, \& Cattaneo, 2010, p. 9). The 'new' issues include food safety, the environment and the provision of ecosystem services, the role of biotechnology in agricultural production (particularly genetically modified organisms, GMOs), intellectual property rights and biopatents, the use of farmland for bioenergy production, and most recently the farm sector's role in climate change mitigation.

In developing countries, the past emphasis on industrial development at the expense of the farm sector has been displaced, and the words 'development' and 'agriculture' are increasingly linked. This was marked by the Maputo Declaration of $2003,{ }^{1}$ for example, in which African Heads of State committed themselves to allocating at least $10 \%$ of their national budgets to investment in agriculture; the publication of the World Bank's Annual Development Report for 2008 with the title Agriculture for Development; and the renewed interest the international aid agencies have taken in the agricultural policies of developing countries in an attempt to raise agricultural productivity and output as a means to achieve the illusive UN Millennium Development Goal of halving poverty and hunger by 2015. In subSaharan Africa this is increasingly urgent as populations continue to grow more rapidly than agricultural productivity. Indeed, in some countries, the production of food-crops has been declining. Value conflicts have often occurred between the Western donors, who prefer a market-driven development process, and recipient governments who often argue for government support to, and intervention in, agriculture.

These developments have resulted in a broadening of the agricultural policy agenda with agricultural policy issues now interlinking with other policy domains (food safety, energy supplies, environmental protection, development aid, etc.), involving new actors promoting values which sometimes conflict, or are not always easily reconcilable, with those previously guiding agricultural policy.

In contrast to traditional farm income support, where policy making was controlled by a single or a well-integrated set of domestic complementary institutions, the new policy issues are dealt with in a more fluid institutional context in which national, regional and global institutions based upon different, and often conflicting, values interact. This has led to a need for more coordination. This process of coordinating policies hosted in different policy sectors, we refer to as inter-institutional policy making. It describes a situation in which existing policies have opened to broader interests. These new policy issues have ramifications for interest groups and government agencies in other policy arenas, and so they too become involved in the development of the new 'agricultural' policies. This development is often associated with overlapping institutional jurisdictions and clashes between competing values at the national or international level. The articles to follow explore how policy makers deal with multi-institutional policy processes, and analyse and explain how policies emerging from such processes are designed and implemented. It is shown that the agricultural policy sector is increasingly decompartmentalised, with new actors and new institutions bringing new values into the policy debate. As a result value balancing has become a pivotal feature of the 'new' politics of agriculture and food. The case studies mainly focus on the agricultural policy sectors of developed economies but also include a study of a developing country, illustrating that value conflicts are not restricted to developed countries.

Most of the articles in this themed issue were first presented at the annual conference of the British Agricultural Economics Society, in April 2011 at the University of Warwick, in three contributed paper sessions devoted to contemporary issues in the politics of agriculture and food. Subsequently they were refocused as necessary on the theme of this special issue.

\section{Agricultural policy studies and their contribution to policy analysis}

Past studies of agricultural policy-making have contributed to theoretical developments in political science within a number of fields, including: interest groups, policy networks, and ideas in public policy. Indeed, some of the classic studies on these concepts were grounded in agricultural policy, and often examples were drawn from the agricultural

\footnotetext{
${ }^{1}$ A copy of which is annexed to FAO (2004).
} 
sector to illustrate theoretical points. What made the agricultural policy sector attractive to scholars engaged in the theoretical development of policy studies was the compartmentalised policy-making process, well-organised and well-resourced farm groups, substantial government intervention in the market, and the potential for a significant redistribution of income and wealth between economic actors.

Some of the influential studies on the role and impact of interest groups in public policy were based on the examination of farm groups, for instance Olson's (1965) classic book on the logic of collective action. This argued that lobbying would be more successful if a group consists of a relatively small number of stakeholders with each having significant potential gains from engaging in political lobbying activities. Compared with their 'natural' opponents in agricultural policy making-consumers and taxpayers-farmers in developed economies are relatively few and can more easily organise to lobby for favourable policies. ${ }^{2}$ Consumers and taxpayers are much more difficult to organise for collective action because of their large numbers, and the fact that their individual gains from engaging in such activities are small and not easily perceived (e.g. Nedergaard, 2006). Amongst agricultural economists a rich political economy literature (reviewed in de Gorter \& Swinnen, 2002) parallels this, driven in the main by economic forces and rent-seeking behaviour; for example Anderson and Hayami's (1986, p. xi) exploration of the 'politico-economic reasons for countries switching from taxing to assisting agriculture in the course of an economy's development', and Swinnen's (2008) analysis of the 2003 CAP reform drawing on contributions from a number of disciplinary traditions. ${ }^{3}$ These differences in the incentives to organise collective action around farm policy making are an important reason why the policy field became compartmentalised and involved mainly farm group representatives, officials of agricultural ministries and departments, and farm politicians elected in rural constituencies, and why it led to the adoption of policies which were beneficial to farmers.

Many works in the American pluralist debate also benefitted from the study of agricultural policy making. For instance, McConnell (1967) and Lowi (1969) argued that power in US agricultural policy making was not concentrated on a few groups but instead dispersed to a number of commodity groups in a highly fragmented policy making system allowing these to control policy making, undermining broader policy coherence. In a later study Browne (1988) broadly supported this conclusion but argued that influence was further dispersed, arguing that many interest groups in the agricultural policy domain had found their own policy niches. As he suggested (1988, pp. 247-248): 'Most private interests are intensively focused organizations with such narrow concerns that they almost never address issues of general economic or social concern'. In the UK, Self and Storing's (1962) seminal study of the relationship between the National Farmers' Union and the British state diverged from the pluralist perspective and emphasised that the relationships between the state and farm groups could develop into institutionalised partnerships, as enshrined in the UK's 1947 Agriculture Act and the annual farm price review. It was not until a decade later that such relationships between government and interest groups gained more scholarly attention (Heisler \& Kvavik, 1974). The concept of neo-corporatism (Schmitter, 1974) was developed to characterise the phenomenon in which interest associations became deeply involved in not only the formulation but also the implementation of public policies. As theories of the 1970s, the empirical focus of neo-corporatist research was on macro-economic policy making involving the peak organisations of labour and capital. Since the neocorporatist school had a preference for macro-level analysis, agricultural policy studies did not figure prominently in this research tradition. However, there are important exceptions, in particular after Cawson (1985) introduced neo-corporatism at the meso-level of analysis. Keeler (1987) showed that the concept of corporatism could be utilised to analyse French agricultural policy. Other studies demonstrated that it was particularly useful in the dairy sector (e.g. Atkinson \& Coleman, 1985; Grant, 1985; Van Waarden, 1985) as well as in the food processing industry where so-called private interest governments, in which governments had devolved regulatory functions to business associations, could be found (Grant, 1987). Neo-corporatism, in particular when applied at the meso-level of analysis, emphasised the compartmentalised nature of public policy making, not least in the agricultural sector.

\footnotetext{
${ }^{2}$ This is in stark contrast to African countries where farmers formed the majority of the population but were typically scattered over large areas and very difficult to organise. This resulted in a so-called urban bias, in that urban interests (e.g. in the form of artificially low food prices) were favoured at the expense of the rural population (Bates, 1981; Lipton, 1977).

${ }^{3}$ Sumner, Alston, and Glauber (2010, p. 411), however, somewhat caustically comment: 'Political economy models have provided some insight into agricultural policy outcomes, but much of the policy process is not well captured in the simple and parsimonious models that have been used'.
} 
While agricultural policy studies had limited influence on the conceptual development of neo-corporatism, they had a much more prominent role in the development of the literature on policy networks and particularly on the development of the concept of a policy community. Most network analysts use the policy community concept to characterise and describe a tight, closed, highly integrated and highly institutionalised network, in which membership is very restricted. The conceptual development of network analysis benefitted from the insights obtained from studying agricultural policy-making. Several studies demonstrated that the policy network concept was useful in analysing agricultural policy making in Britain (Jordan, Maloney, \& McLaughlin, 1994; Smith, 1990), Denmark (Daugbjerg, 1998), France (Epstein, 1997), Ireland (Adshead, 1996), Northern Ireland (Greer, 1994), the EU (Daugbjerg, 1999; Pappi \& Henning, 1999), Australia (Botterill, 2005), Canada and the United States (Coleman et al., 1997) and in crossnational studies of policy networks in the dairy sector (Grant, 1992), the agricultural credit sector (Grant \& McNamara, 1995) and the organic farm sector (Greer, 2002; Tomlinson, 2010). Critiquing the neo-corporatist literature for its predominately macro-level focus on public policy making, network analysts disaggregate the analysis to the meso-level, arguing that macro-level analysis misses the significant variance in policy-making arrangements across policy sectors. Agricultural policy was the archetypical case of policy making through policy communities in which farm groups and agricultural ministries controlled policy making, excluding or marginalising consumer, taxpayer, environmental and nature conversation interests, and most often side-lining treasuries and trade ministries. Further development of the policy network approach, dialectical network analysis, has also benefitted from studies of agricultural policy (Marsh \& Smith, 2000; Toke \& Marsh, 2003).

The punctuated equilibrium model shares with the network approach the notion of policy making taking place in sub-systems, but is more concerned with explaining policy change in a longitudinal perspective. Policy subsystems, involving only a restricted number of political actors with a particular policy interest, control policy making on the basis of a shared view (image) on what is the purpose of the policy and how policy problems should be addressed. The sub-systems may be challenged by outside actors who question the dominant policy frame. These processes are usually relatively short and contentious and threaten the institutional equilibrium. This may result in a re-structuring of the sub-system or the established sub-system may regain control over policy making (Baumgartner \& Jones, 1993). The punctuated equilibrium model qualifies as a relevant theoretical approach to analyse agricultural policy changes and has proven to be so in previous studies (Daugbjerg \& Studsgaard, 2005; Sheingate, 2000; Worsham, 2006). Though the punctuated equilibrium model provides a more elaborated analytical tool to analyse the process of policy change than policy network analysis, it remains an analytical model for policy change rather than an analytical model for inter-institutional policy making in which core policies are maintained but inter-linked with other policy fields.

Studies of farm policy also engaged with the vast institutionalist literature, although not to the extent one might have expected. Considering that such writings developed into a major school in political science it is somewhat surprising that agricultural policy bodies have not attracted more attention despite their relevance for the institutionalist argument. Agricultural policies are highly institutionalised, and still to a considerably extent reflect the past power relations of the 1930s and the immediate post-war period when farm interests had a strong political voice. In the 2010s, agriculture has a small, and declining, importance in employment and income generation in most developed countries, but its political importance is well beyond its economic impact. With the exception of Australia and New Zealand (see Cockfield \& Botterill, 2012), and the momentary interruption by the Federal Agriculture Improvement and Reform (FAIR) Act of 1996 in the US (Orden, Paarlberg, \& Roe, 1999), agricultural policies in developed countries still rest on agricultural exceptionalism and thus provide substantial assistance to farmers. However, agricultural policies have been continuously adjusted, implying that the way in which farmers are subsidised has changed; for instance price support has been transformed to direct farm payments. This type of policy evolution lends itself to an institutionalist analysis and fortunately some agricultural policy analysts have engaged with it. For instance, Ackrill (2005) identifies the budgetary balance between the member states of the European Union as a key reproduction mechanism of the Common Agricultural Policy (CAP). Kay (2003) takes a more dynamic and innovative historical institutionalist perspective on the evolution of the CAP when explaining the substantial policy reforms of 1992. Skogstad's (2005) and Botterill's (2011) analyses of the Canadian and Australian wheat boards are yet other examples demonstrating how the study of agricultural policy has contributed to broader theoretical debates. Both studies provide interesting insights into the way in which institutional reproduction mechanisms can influence institutional transformation differently. Whereas the Canadian Wheat Board persisted, the Australian Wheat Board eventually demised despite a seemingly successful transformation. Patashnik's (2003) study of the fate of the US 1996 
FAIR Act—an agricultural policy reform aimed at phasing out income support—demonstrates how the lack of accompanying institutional reform lead to a rollback of the reform a few years later.

Research on the role of ideas in public policy has also benefitted from insights obtained from the study of agricultural policy. Originally, the theory was developed for macro-economic policy making, focussing on radical change (Blyth, 2002; Hall, 1993), but studies of agricultural policy reforms pointed towards the need for more refinement of the theoretical argument to take into account more nuanced and gradual ways of reforming policy (Coleman et al., 1997; Daugbjerg \& Swinbank, 2009; Daugbjerg, 2008; Feindt, 2010; Garzon, 2006; Lynggaard, 2007; Roederer-Rynning, 2007; Skogstad, 1998, 2008).

Although agricultural policy studies require a considerable effort to understand the detailed complexity of the policy system, they never developed into a sub-discipline with its own sectorial theories. Agricultural policy analysts took care to situate their work in the public policy literature, engaging with theoretical developments within political science. An important motivation for undertaking scholarly work on agricultural policy was to shed new light on phenomena of broader theoretical interest.

\section{From compartmentalised to inter-institutional policy making}

The orthodox approach to studying public policy has been to focus on a particular institution (or governance arrangement). As shown above, this perspective also characterised agricultural policy studies in the past. The agri-food sector is a powerful example of a policy complex that can no longer be analysed on a functional or sectoral basis. It is a difficult case for much of the conventional conceptual architecture of policy studies. Focusing on the new politics of food and agriculture enables us to analyse what happens to a relatively closed policy sector, with well-established institutions based on shared values, when new policy issues influenced by alternative values hosted in alternative venues are put onto the policy agenda. However, the end of agricultural policy compartmentalisation has not necessarily resulted in a broadening of the traditional agricultural policy agenda, which in many countries remains concerned with farm incomes and is still underpinned by agricultural exceptionalism, albeit frequently disguised as multifunctionality. Multifunctionality, bringing other values into the policy-making process, is the notion that agriculture can provide a number of environmental and social services that are valued by society; but that, as these are not easily marketed, they are likely to be under-supplied unless governments intervene to reward farmers for their provision. However, in Australia and New Zealand events took a different turn. The policy reforms in New Zealand resulted in a rapid shift from agricultural exceptionalism to market liberalism while the policy change in Australia was more gradual, and also resulted in a decompartmentalisation of the agricultural policy sector.

Once agriculture compartmentalization breaks down, spillovers break out, and governments, their departments and agencies, and attendant networks, become entangled in clashes between institutions with overlapping jurisdictions and competing values which have to struggle to coordinate multiple policy-making processes. This may easily result in uncoordinated policies.

The 'new' issues-some are not so new any longer-emerging on the agricultural policy agenda include the environment and the provision of ecosystem services, food safety, animal welfare, the role of biotechnology in agricultural production (particularly GMOs), intellectual property rights and bio-patents, the use of farmland for bioenergy production, poverty and food security in developing countries and most recently the farm sector's role in climate change mitigation. Environmental protection and food safety are not new issues. Food safety regulations have a long history, dating back in the UK for example to the food adulteration scandals of the $19^{\text {th }}$ Century (for some of the grisly detail, see Collins, 1993). Rachel Carson's controversial critique of the use of pesticides, Silent Spring, was published in 1962, and Ruth Harrison's exposé of intensive livestock production, Animal Machines, in 1964. The Soil Association - which describes itself as 'the UK's leading membership charity campaigning for healthy, humane and sustainable food, farming and land use'-was founded in $1946 .^{4}$

In the main, however, farmers were still seen as the guardians of the countryside, until these 'new' issues became highly politicised in northern Europe in particular in the 1980s and 1990s, and other interests began to challenge orthodox farm policy. What was different from earlier times was that the issues could no longer be contained within closed agricultural policy networks. The public debate focussed on a variety of concerns associated with 'modern'

${ }^{4} \mathrm{http} / / /$ www.soilassociation.org/aboutus/whoweare (accessed 26.01.12). 
agriculture, for example: the look of the countryside following the removal of hedges and woods, and its capacity to support a rich variety of fauna and flora; nitrate run-off from intensively stocked and fertilised fields; and the impact on animal welfare, and animal and human health, perhaps epitomised by the BSE (Bovine spongiform encephalopathy) scandal in the UK.

The pollution said to be linked to intensive farming methods and the concentration of livestock production, mobilised European environmental groups supported by environmental protection agencies demanding stricter agrienvironmental regulations. Though the agricultural policy networks remained powerful, controlling significant technical expertise which was brought into the detailed and technical negotiations on the design of new policy measures, farm groups and farm ministries to a considerable extent lost control over the policy agenda (e.g. Daugbjerg, 2005). A similar trajectory characterised the development of new European food safety regulations. The BSE crisis demonstrated how the farming and food processing industries, in close coalition with the agricultural authorities, had captured food safety regulation (Baggot, 1998). The crisis mobilised consumer interests and the public and this influenced members of the European Parliament to persuade the European Commission to undertake substantial institutional changes separating farm and food safety interests. This was done by creating a Directorate General for Health and Consumers (DG Sanco) and the European Food Safety Authority (Roederer-Rynning \& Daugbjerg, 2010).

The decompartmentalisation of agricultural policy making can be explained by the consequences of compartmentalisation and by changing political contexts. Compartmentalisation of agricultural policy meant that only a limited number of concerns were taken into account in policy making. Traditional agricultural policy was mainly concerned with maintaining or increasing farm incomes and raising productivity. Little attention was devoted to the risks of environmental degradation resulting from intensive farming, or to consumer concerns about the way in which food is produced and the perceived (rather than real) health risk related to food consumption. ${ }^{5}$ Nor was much concern paid to the impact of developed economies' farm subsidy schemes and border protection on developing countries. As Grant (2012) shows, in parallel with the modernisation and intensification of agricultural production, a number of consumer, environmental, human rights, animal welfare and Global South groups increasingly publicised the negative consequences of modern agricultural production. These groups had emerged from the late 1960 onwards as cause groups, which diverged from traditional interest groups by not acting as representatives of well-defined constituencies, but rather by acting in solidarity with broader constituencies. From the mid-1980s, these groups increasingly directed their attention to the negative consequences of agricultural policies and were able to mobilise public emotions.

This first wave of decompartmentalisation was driven by the negative externalities of intensive agricultural production. The second wave was more focussed on positive externalities. In part orchestrated by the farm lobby, policy makers stressed the positive cultural and environmental impacts of farming: in the EU the language was of a 'European model of agriculture' and of 'multifunctionality' (see for example Commission of the European Communities, 1998, p. 8). Although agriculture is a major source of greenhouse gas emissions, and is under pressure to mitigate this by adopting new and improved farming practices to reduce emissions and capture carbon, there was for a time an enthusiastic belief that agriculture could contribute to climate change mitigation through the production of biofuel.

\section{Balancing values}

Irrespective of whether or not the focus has been on the negative or the positive externalities of agricultural production, it has had the impact of decompartmentalising agricultural policy making, with other venues and interest groups now engaged in inter-sectoral policy making over a range of over-lapping policy concerns. The mobilisation of new actors and new institutions in agricultural policy making have brought new values into the policy debate and led to a situation in which values must be balanced. This is the overarching theme of the articles in this collection.

In every field of public policy competing values exist (Stewart, 2009, p. 2). Intuitively, many people would have a sense of what the concept of values means. However, as an analytical concept, that of values is not very precise and has been used in a variety of meanings (see Daugbjerg \& Botterill, 2012). For Stewart (2009, p. 14) 'policy values are valued ends embodied in, and implemented through, the collective choices we make through policy processes'. Policy

\footnotetext{
${ }^{5}$ Some of these issues were addressed in a collection of articles in Public Administration (see Lowe et al., 2010 for an overview).
} 
values are conceptually distinct from political values. While the latter usually refers to broad and encompassing ends, such as freedom, democracy and equality, '[p]olicy values manifest themselves in particular areas of government action' (Stewart, 2009, p. 14). The concept of values is not easily distinguishable from the concept of ideas because the latter is often defined somewhat inclusively to encompass a cognitive notion of how the world is put together and a normative statement on what implication this ought to have for public policy (e.g. Hall, 1993). For instance, agricultural exceptionalism is both a cognitive notion about the unique nature of the farming industry and a normative statement on the need for special policy treatment of the farming sector. Here, we reserve the concept of ideas for narratives linking events in causal order and thereby providing meaning to certain situations, and the concept of values for the normative dimension of public policies.

In a number of instances, value conflicts within a policy sector cannot readily be identified. Some values may not be voiced in the policy process. But the absence of an overt value conflict does not necessarily indicate that a consensus on value balancing has been achieved. It may well be an outcome of institutional arrangements designed to privilege one particular value and suppress competing values in the policy debate (Baumgartner \& Jones, 1993; Worsham, 2006, p. 438). This is often the situation in a compartmentalised policy-making system such as in most post-war agricultural policy networks in which agricultural exceptionalism was the dominant value. Much discontent over public policy can be boiled down to different normative positions on the objectives and instruments of policy (Stewart, 2009). Since such fundamental disagreements over policy are based on normative positions, argument and persuasion make little difference in terms of reaching a compromise on one shared value to underpin the policy design. In such situations a balance between values underpinning the policy design has to be established, unless some policy participants are powerful enough to exclude other participants holding different values. Therefore, as Lindblom (1965, p. 227) argued: 'The question of how values are weighted into decisions or resultant states of affairs is central to the study of public decision making'.

As argued above, other policy areas have inter-linked or over-lapped with agricultural policy. Often these have originated in different institutional settings underpinned by values that are not compatible with agricultural exceptionalism. Therefore, ways had to be found to accommodate these values in the policies developed to address new or reframed policy issues that interlinked with agricultural policy. This decompartmentalised agricultural policymaking and forced agricultural policy makers to engage in inter-institutional policy making.

Articles in this issue analyse policy issues in which policy makers have become involved in balancing values. In some situations policy makers did not succeed in this balancing act and one particular value came to prevail. As a result, value conflict hampered the effective resolution of policy problems resulting in unstable policy outcomes. In other situations value conflict has been resolved through institutional design, sometimes by peculiar arrangements. In the longer term, such arrangements may carry the seeds for undermining the very balance they were set up to preserve. As Thacher and Rein (2004, p. 461) point out, institutional design can rarely definitively resolve value conflict. For instance, institutional separation of values is unlikely to prevent a reopening of value conflict because 'institutions can rarely insulate themselves permanently from the values which they try to shed ... One reason for this is that over time, different institutions interact with one another, and the separated system may lose its pure lines of institutional demarcation' (Thacher \& Rein, 2004, pp. 472-473).

This special issue includes two studies in which policy makers failed to find a balance between competing values. Feindt's (2012) analysis of the politics of bio-patents in food and agriculture shows that the attempt to extend the jurisdiction of general patent law into the agricultural sector challenged agricultural exceptionalism. General patent law is based on the view that markets are the best social mechanism for allocating resources. The private appropriation of the exploitation of knowledge through patenting creates incentives for private innovation, for firms can then recoup their investment in R\&D. In other words, despite this 'monopolisation' of knowledge, a market liberal value underpins general patent law. However, as Feindt (2012) points out, 'biotechnological inventions work with existing genetic material, which is often discovered rather than invented; biological material can be replicated or can replicate itself; and the mass production of plants or animals is the central mechanism of value creation in agriculture'. This has raised the question of 'whether biopatents in the food and agriculture sector create problems that require specific exemptions'.

Consequently the extension of patents into the agricultural and food sector triggered a value conflict between market liberalists, who maintained that general patent law was equally applicable for food and agricultural innovations, and agricultural exceptionalists, who defended the exclusions which had applied until the early 1980s (when new inventions in biotechnology had begun to challenge agricultural patent law). Ever since there has been a continuous conflict in which no stable balancing of values has occurred. Though agricultural exceptionalists 
eventually gained the upper hand, it remains to be seen whether this is a stable outcome of a long value conflict over bio-patenting.

Kjær and Joughin's (2012) analysis of the privatisation of the agricultural extension service in Uganda also presents a case in which conflicting values were not balanced in the institutional design. Although they do not use the concepts of agricultural exceptionalism and market liberalism, the case does parallel the conflict in bio-patenting in failing to balance competing values. Until privatisation in 2001, the extension service had been run by the government and resembled an agricultural exceptionalist approach in which an important role was reserved for the state in developing the agricultural sector. The market had been seen as a sub-optimal means to bring about desired outcomes. The market liberalisation of the extension service was strongly supported by Uganda's development partners and by technocrats in the Ugandan Ministry of Finance and Economic Planning. The reform (the new National Agricultural Advisory Services, or NAADS) foresaw a switch from a traditional top-down government-led extension service to a privatised, demand-led one in which farmers were supposed to define their own requirements. However, the reform was suspended twice, drastically re-moulded, and to some extent turned on its head, to re-emerge as a government extension service once again. The NAADS programme represented market liberal values that were apparently not shared by large parts of the Ugandan polity. Key stakeholders, notably local politicians and the Ministry of Agriculture, Animal Industries and Fisheries, were excluded from the original programme and this threatened its viability. Eventually agricultural exceptionalism, with its key role for the state in developing the agricultural sector, prevailed.

In other situations, policy makers have been more successful in balancing values and defusing value conflicts - at least in the short term. Kay and Ackrill's (2012) analysis of biofuel policies in the EU and the US demonstrates that a number of competing and incommensurate values were accommodated in the design of the biofuel policies of the EU and the US by a strategy of temporal separation. Some values (e.g. sustainability) were given superordinate goal status but pushed into the longer term; others (e.g. rural development) were enshrined in shorter-term objectives. This temporal separation has meant that a number of organisations with overlapping jurisdictions are involved in the implementation of a transition towards a biofuel transport economy. The temporal strategy has served to balance values, but whether the strategy can be successfully implemented in the longer term, preserving the value balance, is uncertain. The value balance is premised on the expectation that biofuel production can be shifted from firstgeneration production technologies, which use known agricultural feed-stocks with associated land use change and food production effects, to advanced technologies which use biomass that does not compete directly, or indirectly, with food production. This means that without the ability to commit credibly to the longer-term value of sustainability, the viability of the policy strategy to accommodate conflicting values through temporal separation may collapse, resulting in a reopening of value conflict.

Daugbjerg and Botterill's (2012) analysis of the emergence of ethical standards in the global food trade regime also demonstrates that competing values can be balanced through a somewhat uneven institutional arrangement. Using organic farming standards and the private global food standard scheme, GlobalGAP, as their examples, they show how these two regimes exist in parallel with the WTO's SPS (Sanitary and Phytosanitary) and TBT (Technical Barriers to Trade) agreements. To the extent that GlobalGAP and organic farming standards embody ethical values for food production that are not covered by the WTO agreements (which are instead based on values privileging free trade and scientific evidence) the broader institutional arrangement would appear to have a built-in value conflict. Despite this apparent conflict, the emergence of food standard schemes based on ethical values, and existing in parallel with the WTO agreements, has not undermined these two WTO agreements. Furthermore, this arrangement of parallel institutions, emerging independently of each other, seems to have prevented value conflict from being reopened in the on-going Doha Round negotiations of the WTO. Though it appears relatively stable, it may nonetheless carry the seeds for its own destruction in the longer term because the private standard schemes, in particular GlobalGAP, may undermine scientifically based international standards as the core value underpinning the SPS Agreement. By urging governments to use international scientific standards, the SPS Agreement sought to create a level playing field for food trade. The emergence of standard schemes in the private sector, which is not obliged to apply these standards and often diverges from them, threatens to hamper the creation of a transparent system for standards in world food trade.

Cockfield and Botterill's (2012) analysis of the evolution of rural policies in Australia and New Zealand is an example of successful value rebalancing. In both countries, agricultural exceptionalism was abolished and replaced by economic liberalism in the 1980s. This shift did not, however, imply that the negative externalities, which an unregulated agricultural market was believed to produce, were neglected. As they demonstrate, regional spatial equity 
and environmentalism have become important in the two countries, and environmental and rural policy programmes have been put in place to address these values. Such programmes could potentially challenge economic liberalism, but in the Australian and New Zealand examples they have been shaped on the basis of economic liberalism.

Greer and Hind (2012) analyse what is perhaps a value conflict in the making. Despite the rhetoric of multifunctionality, and major changes in the way European farmers are supported as a result of successive reforms brought about in part by pressures from its WTO partners, the EU's CAP still reflects its roots in agricultural exceptionalism (Daugbjerg \& Swinbank, 2009, 2011). A new 'reform' to define the shape of the post-2013 CAP has been launched, the outcome of which is currently unclear (Swinbank, 2012). One constraint that differs in this 'reform' debate from that of previous reforms is the new decision-making procedures over the CAP following ratification of the Treaty of Lisbon. How these new provisions will play-out is the focus of Greer and Hind's (2012) contribution. Although they have, as yet, only one substantive policy decision to examine (changes to the dairy regime), and no counterfactual to compare, there is no hint in their analysis to suggest that the tensions in the EU between those who champion agricultural exceptionalism and those that advocate market liberalism will be lessened. Indeed, as they point out, the existing European Parliament Committee on Agriculture (COMAGRI) is itself an example of compartmentalism, and they note that 'In late $2011 \ldots 11$ of its 45 full members were current or ex-farmers, six were ex-agriculture ministers, four had worked in the industry, and many of the rest had some relevant agricultural interest or background; of the six members from the UK, five indicated a direct background in farming.' The latter is hardly a representative sample of the UK population.

\section{Conclusions}

In the toolbox of public policy analysis, we have theories to explain policy stability (neo-corporatism, policy network analysis, neo-institutionalism with its focus on path dependency) and these have proven effective in identifying the mechanisms that reproduce stable agricultural policy paths over time. These theories stress the importance of compartmentalised policy making involving only a limited number of interests that share ideas and values. The wave of policy reforms of the 1980s and 1990s directed the attention of policy analysts towards developing theories and analytical frameworks which could be applied to explain these changes (the multiple streams model, punctuated equilibrium model, the advocacy coalition framework, ideational theory). These theories shared with 'stability theories' the notion of routine policy-making taking place in relatively closed and exclusive sub-systems, or networks. Policy making in these compartmentalised structures, or policy communities, addresses only a limited number of policy problems and issues. When new issues emerge on the policy agenda as result of broader political, socio-economic, or technological changes in society, new actors (political entrepreneurs, interest groups or government agencies) affected by these contextual changes but not previously involved in the compartmentalised subsystems, or networks, may focus their attention onto the policy outcomes of these sub-systems. The sub-systems may have become unable to respond to these broader contextual changes in a way that satisfies a broader constituency. Moreover, as Grant (2012) argues, by using new modes of action (such as social media), new actors may be able to 'open up debate and ... challenge established policy discourses.' As a consequence, these new actors may succeed in initiating and forcing through policy reform and institutional change.

What these theories do not explain well, or do not address at all, is the phenomenon by which compartmentalised policy making is opened to outsiders whilst the basic structure of the sector's core policies remains more or less untouched. Thus, policy change can be much less dramatic than these theories tend to depict since it may emerge from a process of inter-institutional coordination rather than through a process in which core policies are subject to a frontal attack aimed at fundamental reform changing the basic objectives and policy instruments. Inter-institutional coordination links the core policy sector with new policy arenas which had not previously engaged with the core policy sector, or had done so only infrequently. This less politically costly strategy invoked by such new actors may be to initiate a process of policy layering in which the new policy concerns are addressed by adding new measures to the existing core policy. The concept of policy layering has not been explicitly defined, but Thelen's (2003, p. 228) definition of institutional layering may also cover policy layering. Layering refers to a 'process that preserves much of the core [of an institution] while adding amendments through which rules and structures inherited from the past can be brought into synch with changes in the normative, social, and political environments' (Thelen, 2003, p. 228).

As the case studies of this special issue demonstrate, decompartmentalisation and inter-institutional policy making, which may result in policy layering, involves value balancing. What is also shown in the case studies is that this is not 
an easy process. Inter-institutional policy-making may become contentious and as result no balancing of values will take place, as shown by Feindt (2012) and by Kjær and Joughin (2012). These articles also demonstrate that values should not be ignored by policy makers.

The case studies by Kay and Ackrill (2012) and Daugbjerg and Botterill (2012) show that values can be balanced through policy layering, although this may only have the potential to defuse value conflict in the short and medium term. Policy layering may have a built-in tension, which may reopen value conflict in the longer term as the institutional arrangements established to balance competing values become unable to keep such conflict at bay. This situation is likely to occur when the value balance is changed as a result of a shift in political or economic relationships in the context external to such institutional arrangements. In other words, policy layering is unlikely to become a long lasting stable solution in inter-institutional policy making. More research is needed to establish whether it is an intermediate stage in a full-scale long-term policy transformation. The most stable solution to inter-institutional policy making appears to be when one overarching value dominates the policy complex, as demonstrated by Cockfield and Botterill (2012).

The articles that follow demonstrate that decompartmentalisation and inter-institutional policy-making are becoming increasingly important in the agricultural policy sector. They demonstrate that analyses of how these new policy concerns in the agricultural policy sector are addressed have the potential to provide theoretical insights in much the same way as did past studies of traditional agricultural policy. As in the past the contributors to this special issue are firmly engaged with the broader theoretical developments in political science, which enables them to extract the more general lessons from their case studies.

\section{References}

Ackrill, R. (2005). The common agricultural policy. In P. van der Hoek (Ed.), Handbook on public administration and policy in the European Union (pp. 435-487). Boca Raton: Taylor \& Francis.

Adshead, M. (1996). Beyond clientelism: Agricultural networks in Ireland and the EU. West European Politics, 19(3), 583-608.

Anderson, K., \& Hayami, Y. (Eds.). (1986). The political economy of agricultural protection: East Asia in international perspective. Sydney: Allen \& Unwin.

Atkinson, M. M., \& Coleman, W. D. (1985). Corporatism and industrial policy. In A. Cawson (Ed.), Organized interests and the state: Studies in meso-corporatism (pp. 22-44). London: Sage.

Baggot, R. (1998). The BSE crisis: Public health and the 'risk society'. In P. Gray \& P. 't Hart (Eds.), Public policy disasters in Western Europe (pp. 61-78). London: Routledge.

Bates, R. H. (1981). Markets and states in tropical Africa. The political basis of agricultural policies. Berkeley: University of California Press. Baumgartner, F. R., \& Jones, B. D. (1993). Agendas and instability in American politics. Chicago: The University of Chicago Press.

Blyth, M. (2002). Great transformations: Economic ideas and institutional change in the twentieth century. Cambridge: Cambridge University Press.

Botterill, L. (2005). Policy change and network termination: The role of farm groups in agricultural policy making in Australia'. Australian Journal of Political Science, 40(2), 207-219.

Botterill, L. (2011). Life and death of an institution: The case of collective wheat marketing in Australia'. Public Administration, 89(2), 629-643.

Browne, W. P. (1988). Private interests, public policy and American agriculture. Lawrence: Kansas University Press.

Carson, R. (1962). Silent spring. Boston: Houghton Mifflin Company.

Cawson, A. (1985). Introduction. Varieties of corporatism: The importance of the meso-level of interest intermediation. In A. Cawson (Ed.), Organized interests and the state: Studies in meso-corporatism (pp. 1-21). London: Sage.

Cockfield, G., \& Botterill, L. C. (2012). The evolution of rural policy: The Antipodean experience. Policy \& Society 31(4)http://dx.doi.org/10.1016/ j.polsoc.2012.09.006.

Coleman, W. D., Skogstad, G. D., \& Atkinson, M. M. (1997). Paradigm shifts and policy networks: Cumulative change in agriculture. Journal of Public Policy, 16(3), 273-301.

Collins, E. J. T. (1993). Food adulteration and food safety in Britain in the 19th and early 20th centuries. Food Policy, 18(2), 95-109.

Commission of the European Communities. (1998). Proposals for Council regulations (EC) concerning reform of the common agricultural policy, COM(1998)158. Brussels: CEC.

Cox, G., \& Lowe, P. (1983). Countryside politics: Goodbye to goodwill? The Political Quarterly, 54(3), 268-282.

Daugbjerg, C. (1998). Policy networks under pressure: Pollution control, policy reform, and the power of farmers. Aldershot: Ashgate.

Daugbjerg, C. (1999). Reforming the CAP: Policy networks and broader institutional structure. Journal of Common Market Studies, 37(3), 407-428.

Daugbjerg, C. (2005). Uniting to meet challenges: Danish farm interest groups in the 21st century'. In Darren Halpin (Ed.), Surviving global change? Agricultural interest groups in comparative perspective (pp. 71-89). Aldershot: Ashgate.

Daugbjerg, C. (2008). Ideas in two-level games: The EC-United States dispute over agriculture in the GATT Uruguay round. Comparative Political Studies, 41(9), 1266-1289.

Daugbjerg, C., \& Botterill, L. C. (2012). Ethical food standard schemes and global trade: Paralleling the WTO? Policy \& Society 31(4)http:// dx.doi.org/10.1016/j.polsoc.2012.09.003. 
Daugbjerg, C., \& Studsgaard, J. (2005). Issue redefinition, venue change and radical agricultural policy reforms in Sweden and New Zealand. Scandinavian Political Studies, 28(2), 103-124.

Daugbjerg, C., \& Swinbank, A. (2009). Ideas, institutions, and trade: The WTO and the curious role of EU farm policy in trade liberalization. Oxford: Oxford University Press.

Daugbjerg, C., \& Swinbank, A. (2011). Explaining the 'Health Check' of the common agricultural policy: Budgetary politics, globalisation and paradigm change revisited. Policy Studies, 32(2), 127-141.

de Gorter, H., \& Swinnen, J. (2002). Political economy of agricultural policy. In Gardner, B. L., \& Rausser, G. C. Eds. Handbook of agricultural economics, agricultural and food policy. vol. 2B (pp.1893-1943). Amsterdam: Elsevier.

Eisenhower, D. D. (1956). Special message to the congress on agriculture, 9 January. J. T. Woolley \& G. Peters. The American Presidency Project. Santa Barbara, CA. Available at: http://www.presidency.ucsb.edu/ws/?pid=10756.

Epstein, P. J. (1997). Beyond policy community: French agriculture and the GATT. Journal of European Public Policy, 4(3), $355-372$.

FAO (Food and Agriculture Organization). (2004). Implementation of the comprehensive Africa agriculture development programme (CAADP) of NEPAD - progress review. Twenty-third regional conference for Africa Archived at: http://www.fao.org/docrep/meeting/007/J1604e.htm.

Feindt, P. H. (2010). Policy learning and environmental policy integration in the common agricultural policy, 1973-2003. Public Administration, $88(2), 296-314$

Feindt, P. H. (2012). The politics of biopatents in food and agriculture, 1950-2010: Value conflict, competing paradigms and contested institutionalisation in multi-level governance. Policy \& Society 31(4)http://dx.doi.org/10.1016/j.polsoc.2012.09.002.

Garzon, I. (2006). Reforming the common agricultural policy: History of a paradigm change. Basingstoke: Palgrave.

Grant, W. (1985). Private organizations as agents of public policy: The case of milk marketing in Britain. In W. Streeck \& P. C. Schmitter (Eds.), Private interest government: Beyond market and state (pp. 182-196). London: Sage Publications.

Grant, W. (Ed.). (1987). Business interest, organizational development and the private interest government: An international comparative study of the food processing industry. Berlin: Walter de Gruyter.

Grant, W. (1992). Models of interest intermediation and policy formation applied to an internationally comparative study of the dairy industry. European Journal of Political Research, 21(1-2), 53-68.

Grant, W. (1995). Is agricultural policy still exceptional? The Political Quarterly, 66(3), 156-169.

Grant, W. P. (2012). Can political science contribute to agricultural policy? Policy \& Society 31(4)http://dx.doi.org/10.1016/j.polsoc.2012.09.001.

Grant, W., \& McNamara, A. (1995). When policy communities intersect: The case of agriculture and banking. Political Studies, 43(3), 509-515.

Greer, A. (1994). Policy networks and state-farmer relations in Northern Ireland, 1921-1972. Political Studies, 42(3), 396-412.

Greer, A. (2002). Policy networks and policy change in organic agriculture: A comparative analysis of the UK and Ireland. Public Administration, 80(3), 453-473.

Greer, A., \& Hind, T. (2012). Inter-institutional decision-making: The case of the Common Agricultural Policy. Policy \& Society 31(4)http:// dx.doi.org/10.1016/j.polsoc.2012.09.005.

Hall, P. A. (1993). Policy paradigms, social learning, and the state. The case of economic policymaking in Britain. Comparative Politics, 25(3), 275-296.

Halpin, D. (2005). Agricultural interest groups and global challenges: Decline and resilience'. In D. Halpin (Ed.), Surviving global change? Agricultural interest groups in comparative perspective (pp. 1-28). Aldershot: Ashgate.

Harrison, R. (1964). Animal machines: The new factory farming industry. London: Vincent Stuart Publishers.

Hathaway, D. E. (1963). Government and agriculture: Public policy in a democratic society. New York: Macmillan.

Heisler, M. O., \& Kvavik, R. B. (1974). Patterns of European politics: The “European Polity" model. In M. O. Heisler (Ed.), Politics in Europe: Structures and processes in some post-industrial democracies. New York: McKay.

Huang, H., Legg, W., \& Cattaneo, A. (2010). Climate change and agriculture: The policy challenge for the 21st century? EuroChoices, 9(3), 9-14. Jordan, G., Maloney, W. A., \& McLaughlin, A. M. (1994). Characterizing agricultural policy-making. Public Administration, 72(4), 505-526.

Josling, T., Tangermann, S., \& Warley, T. K. (1996). Agriculture in the GATT. Basingstoke: Macmillan.

Kay, A. (2003). Path dependency and the CAP. Journal of European Public Policy, 10(3), 405-420.

Kay, A., \& Ackrill, R. (2012). Governing the transition to a biofuels economy in the US and EU: Accommodating value conflicts, implementing uncertainty. Policy \& Society 31(4)http://dx.doi.org/10.1016/j.polsoc.2012.10.001.

Keeler, J. T. S. (1987). Farmers, the state, and agricultural policy-making in the fifth republic. Oxford: Oxford University Press.

Kjær, A. M., \& Joughin, J. (2012). The reversal of agricultural reform in Uganda: Ownership and values. Policy \& Society 31(4)http://dx.doi.org/ 10.1016/j.polsoc.2012.09.004.

Lindblom, C. E. (1965). The intelligence of democracy: Decision making through mutual adjustment. New York: Free Press.

Lipton, M. (1977). Why poor people stay poor: Urban bias in world development. Cambridge Mass: Harvard University Press.

Lowe, P., Feindt, P. H., \& Vihinen, H. (2010). Introduction: Greening the countryside? Changing frameworks of EU agricultural policy. Public Administration, 88(2), 287-295.

Lowi, T. J. (1969). The end of liberalism: Ideology, policy, and the crisis of public authority. New York: WW Norton and Company.

Lynggaard, K. (2007). The institutional construction of a policy field: A discursive institutional perspective on change within the common agricultural policy. Journal of European Public Policy, 14(2), 293-312.

Marsh, D., \& Smith, M. (2000). Understanding policy networks: Towards a dialectic approach. Political Studies, 48(1), 4-21.

McConnell, G. (1967). Private power and American democracy. New York: Alfred A Knopf.

Nedergaard, P. (2006). Market failures and government failures: A theoretical model of the common agricultural policy. Public Choice, 127(3-4), 385-405.

Olson, M. (1965). The logic of collective action: Public goods and the theory of group. Cambridge, MA: Harvard University Press.

Orden, D., Paarlberg, R., \& Roe, T. (1999). Policy reform in American agriculture: Analysis and prognosis. Chicago: The University of Chicago Press. 
Pappi, F. U., \& Henning, C. H. C. A. (1999). The organization of influence on the EC's common agricultural policy: A network approach. European Journal of Political Research, 36(2), 257-281.

Patashnik, E. (2003). After the public interest prevails: The political sustainability of policy reform. Governance, 16(2), $203-234$.

Roederer-Rynning, C. (2007). Farm conservatism in France: Revisiting the weak state thesis. Journal of European Public Policy, 14(7), 1010-1027.

Roederer-Rynning, C., \& Daugbjerg, C. (2010). Power, learning or path dependency? Investigating the roots of the European food safety authority. Public Administration, 88(2), 315-330.

Schmitter, P. C. (1974). Still the century of corporatism? Review of Politics, 36(1), 85-131.

Self, P., \& Storing, H. J. (1962). The state and the farmer. London: George Allen and Unwin.

Sheingate, A. (2000). Agricultural retrenchment revisited: Issue definition and venue change in the United States and European Union. Governance, 13(3), 335-363.

Skogstad, G. (1998). ideas, paradigms and institutions: Agricultural exceptionalism in the European Union and the United States. Governance, 11(4), 463-490.

Skogstad, G. (2005). The dynamics of institutional transformation: The case of the Canadian wheat board. Canadian Journal of Political Science, $38(3), 529-548$.

Skogstad, G. (2008). Canadian agricultural policy programs and paradigms: The influence of international trade agreements and domestic factors. Canadian Journal of Agricultural Economics, 56(4), 493-507.

Smith, M. J. (1990). The politics of agricultural support in Britain: The development of the agricultural policy community. Aldershot: Dartmouth

Stewart, J. (2009). Public policy values. Basingstoke: Palgrave Macmillan.

Sumner, D. A., Alston, J. M., \& Glauber, J. W. (2010). Evolution of the economics of agricultural policy. American Journal of Agricultural Economics, 92(2), 403-423.

Swinbank, A. (2012). Another reform? Proposals for the post-2013 common agricultural policy. World Agriculture: Problems and Potential, 3(1), 32-37.

Swinnen, J. F. M. (Ed.). (2008). The perfect storm: The political economy of the Fischler reforms of the common agricultural policy. Brussels: Centre for European Policy Studies.

Thacher, D., \& Rein, M. (2004). Managing value conflict in public policy. Governance, 17(4), 457-486.

Thelen, K. (2003). How institutionalism evolve: Insights from comparative historical analysis. In J. Mahoney \& D. Rueschemeyer (Eds.), Comparative historical analysis in the social sciences (pp. 208-240). Cambridge: Cambridge University Press.

Toke, D., \& Marsh, D. (2003). Policy networks and the GM crops issue: Assessing the utility of the dialectical model of policy networks. Public Administration, 81(2), 229-251.

Tomlinson, I. J. (2010). Acting discursively: The development of UK organic food and farming policy networks. Public Administration, 88(4), $1045-1062$.

Van Waarden, F. (1985). Varieties of collective self-regulation of business: The example of the Dutch dairy industry. In W. Streeck \& P. C. Schmitter (Eds.), Private interest government: Beyond market and state (pp. 197-220). London: Sage Publications.

Wilcox, C. (1949). A charter for world trade. New York: Macmillan.

World Bank. (2007). World development report 2008: Agriculture for development. Washington, DC: World Bank.

Worsham, J. (2006). Up in smoke: Mapping subsystem dynamics in tobacco policy. Policy Studies Journal, 34(3), 437-452. 